\title{
Faktor - Faktor yang Mempengaruhi Perkembangan Angkutan Udara Rute Sumenep - Surabaya pp.
}

\section{Factors Affecting Air Transport Route Development of Sumenep - Surabaya Vice Versa.}

\author{
Lestari $^{1, a)}{ }^{\text {Dewanti }}{ }^{2)}$ \& Sigit Priyanto ${ }^{2)}$ \\ ${ }^{1)}$ Mahasiswa Magister Sistem dan Teknik Transportasi, Universitas Gadjah Mada, Yogyakarta \\ ${ }^{2)}$ Departemen Teknik Sipil dan Lingkungan, Universitas Gadjah Mada, Yogyakarta
}

Koresponden : ${ }^{a}$ lestari2018@mail.ugm.ac.id

\begin{abstract}
ABSTRAK
Angkutan udara rute Sumenep - Surabaya pp. mulai beroperasi pada tahun 2015. Pada awalnya rute ini adalah rute angkutan udara perintis yang kemudian berkembang menjadi rute komersial pada tahun 2017. Proses perkembangan dari angkutan udara perintis ke komersial untuk rute Sumenep - Surabaya pp. membutuhkan waktu yang relatif singkat jika dibandingkan dengan rute perintis lain yang pada wilayah kerja Koordinator Wilayah Sumenep. Keberhasilan rute perintis menjadi rute komersial merupakan salah satu indikator keberhasilan fungsi keperintisan. Berdasarkan hal tersebut perlu dilakukan penelitian untuk mengetahui faktor - faktor apa saja yang mempengaruhi perkembangan angkutan udara rute Sumenep - Surabaya pp. Metode penelitian yang digunakan adalah metode kualitatif pendekatan studi kasus. Pengumpulan data dilakukan dengan melakukan wawancara terhadap regulator, operator penerbangan, pengelola bandara dan penumpang serta observasi lapangan. Metode analisis menggunakan kategorisasi fakta fakta sejenis dari data primer dan sekunder, yang kemudian dikelompokkan menjadi sub tema dan tema terkait perkembangan angkutan udara rute Sumenep - Surabaya pp. Berdasarkan hasil pengelompokan tersebut dapat diidentifikasi faktor - faktor yang mempengaruhi perkembangan angkutan udara perintis menjadi angkutan udara komersial. Faktor-faktor tersebut adalah fasilitas bandar udara, dukungan pemerintah, operator penerbangan yang beroperasi, jumlah penumpang, jadwal dan frekuensi penerbangan, harga tiket dan keterhubungan dengan rute lain.
\end{abstract}

Kata Kunci : manajemen aset infrastruktur, angkutan udara, rute perintis, rute komersial

\section{PENDAHULUAN}

Transportasi udara mempunyai fungsi sebagai unsur penunjang (servicing sector) dan unsur pendorong (promoting sector). Fungsi sebagai unsur penunjang berkaitan dengan kemampuan transportasi udara menyediakan jasa transportasi yang efektif dan efisien. Fungsi sebagai unsur pendorong merupakan kemampuan transportasi udara sebagai untuk membuka daerah terisolasi dan daerah - daerah serta pulau - pulau terpencil (Sartono et. al, 2017). Fungsi sebagai unsur pendorong ini sangat penting peranannya dalam mewujudkan konektivitas di Indonesia. Hal ini berkaitan dengan kondisi geografis Indonesia yang sebagian besar wilayahnya terdiri dari pulau dan kepulauan. Transportasi udara mempunyai karakteristik kecepatan tinggi dan dapat melakukan penetrasi sampai ke seluruh wilayah yang tidak bisa dijangkau oleh moda transportasi lain (KM 49/05, 2005). Akan tetapi ditinjau dari pembiayaan, penyelenggaraan transportasi udara membutuhkan biaya yang paling besar jika dibandingkan jenis transportasi lain. Walaupun biaya penyelenggaraannya mahal, transportasi udara harus 
dilaksanakan utamanya untuk menjangkau daerah - daerah terpencil, tertinggal dan aksesibilitas ke daerah lain terbatas. Untuk daerah - daerah tersebut, selain fungsi konektivitas, transportasi udara sangat diperlukan untuk mengurangi disparitas harga terutama kebutuhan pokok masyarakat. Secara komersial, rute - rute untuk daerah terpencil, tertinggal dan aksesibilitas terbatas ini belum menguntungkan sehingga operator penerbangan belum ada yang bersedia untuk melayani. Atas dasar pertimbangan tersebut pemerintah memberikan dukungan dengan menyelenggarakan angkutan udara perintis.

Angkutan udara perintis diselenggarakan oleh Direktorat Jenderal Perhubungan Udara Kementerian Perhubungan. Pada pelaksanaan di lapangan, Direktur Jenderal Perhubungan Udara menunjuk Koordinator Wilayah untuk mempersiapkan, mengawasi dan melaporkan hasil pengawasan pelaksanaan angkutan udara perintis kepada Direktur Jenderal Perhubungan Udara. Evaluasi pelaksanaan angkutan udara perintis dilakukan sekurang - kurangnya 1 tahun sekali oleh Direktur Jenderal Perhubungan Udara, Kantor Otoritas Bandar Udara, Koordinator Wilayah dengan melibatkan Unit Pelaksana Bandar Udara dan Pemerintah Daerah. Pelaksanaan evaluasi berdasarkan fungsi keperintisan, kinerja penyelenggaraan dan pertumbuhan ekonomi serta peningkatan pembangunan infrastruktur daerah. Hasil evaluasi angkutan udara perintis menjadi dasar penetapan apakah suatu rute perintis ditetapkan lagi sebagai rute perintis pada tahun berikutnya, berubah statusnya menjadi komersial atau dihapuskan sebagai rute perintis.

Satu - satunya koordinator wilayah angkutan udara perintis yang berada di Pulau Jawa adalah Koordinator Wilayah Sumenep. Rute - rute angkutan udara perintis pada Korwil Sumenep mulai beroperasi pada tahun 2015 berdasarkan Keputusan Direktur Jenderal Perhubungan Udara Nomor : KP 469 Tahun 2014 tanggal 10 September 2014 tentang Rute dan Penyelenggara Subsidi Angkutan Udara Perintis serta Penyelenggara Subsidi Angkutan Bahan Bakar Minyak (BBM) Tahun Anggaran 2015. Perkembangan rute - rute angkutan udara perintis di Korwil Sumenep mulai tahun 2015 hingga kondisi saat ini (2019) dapat dilihat pada Tabel 1.

Tabel 1. Rute - rute Perintis di Koordinator Wilayah Sumenep

\begin{tabular}{|l|l|l|}
\hline \multicolumn{1}{|c|}{ Rute } & Pelaksanaan & \multicolumn{1}{c|}{ Status } \\
\hline Sumenep - Surabaya pp. & $2015-2017$ & Berubah menjadi rute komersial \\
\hline Sumenep - Jember pp. & 2015 & Dihentikan pelaksanaannya \\
\hline Karimunjawa - Surabaya pp. & 2015 - saat ini & Rute perintis \\
\hline Karimunjawa - Semarang pp. & $2015-2016$ & Dihentikan pelaksanaannya \\
\hline Bawean - Surabaya pp. & 2016 - saat ini & Rute perintis \\
\hline Sumenep - Bawean pp. & 2018 - saat ini & Rute perintis \\
\hline Sumenep - Pagerungan pp. & 2019 & Rute perintis \\
\hline Sumber : Kantor UPBU Trunojoyo, 2019 & \\
\hline
\end{tabular}

Di antara rute - rute perintis yang dikelola oleh Koordinator Wilayah Sumenep tersebut, rute Sumenep - Surabaya pp. mengalami perkembangan paling signifikan. Rute angkutan udara perintis Sumenep - Surabaya pp. telah berhasil berkembang menjadi rute komersial pada tahun 2017. Berubahnya status dari rute perintis menjadi rute komersial menandakan kesuksesan fungsi keperintisan pada rute tersebut. Rute Sumenep - Surabaya pp. telah berhasil menjadi rute komersial yang dioperasikan oleh badan usaha angkutan udara dan telah lepas sepenuhnya dari subsidi pemerintah. Berdasarkan kesuksesan pelaksanaan angkutan udara perintis tersebut, maka dilakukan penelitian yang betujuan untuk mengidentifikasi faktor - faktor apa saja yang mempengaruhi perkembangan rute perintis menjadi rute komersial dengan menggunakan rute Sumenep - Surabaya pp. sebagai studi kasus.

Perubahan angkutan udara dari non komersial ke rute komersial sebelumnya telah diteliti oleh Yuliana (2012). Penelitian ini dilakukan di Bandar Udara Sultan Iskandar Muda - Aceh 
dengan menggunakan metode kuantitatif. Data didapatkan dengan memberikan kuesioner kepada responden terkait faktor - faktor yang mempengaruhi perkembangan tersebut. Berdasarkan analisis statisik deskriptif menurut Yuliana faktor - faktor yang mempengaruhi perubahan rute penerbangan non komersial menjadi rute komersial adalah potensi rute penerbangan, perusahaan angkutan udara yang beroperasi, tarif penerbangan- jaringan angkutan udara serta demand angkutan udara.

Angkutan udara perintis merupakan angkutan udara yang dibiayai dengan subsidi oleh Pemerintah. Agar tidak bergantung kepada subsidi, angkutan udara perintis perlu dikembangkan menjadi angkutan udara komersial. Oleh karena itu, tujuan penelitian adalah untuk mengidentifikasi faktor - faktor yang mempengaruhi perkembangan angkutan udara perintis menjadi komersial. Penelitian ini menggunakan studi kasus rute Sumenep - Surabaya pp. yang telah berhasil mengalami perkembangan dari rute perintis menjadi komersial. Hasil dari penelitian ini diharapkan dapat digunakan sebagai bahan referensi bagi regulator penerbangan, pemerintah daerah dan operator penerbangan dalam melaksanakan evaluasi serta kajian pengembangan rute angkutan udara perintis menjadi rute angkutan udara komersial.

\section{STUDI PUSTAKA}

Berdasarkan Undang - Undang No. 1 Tahun 2009 tentang Penerbangan yang dimaksud dengan angkutan udara perintis adalah kegiatan angkutan udara niaga dalam negeri yang melayani jaringan dan rute penerbangan untuk menghubungkan daerah terpencil dan tertinggal atau daerah yang belum terlayani oleh moda transportasi lain dan secara komersial belum menguntungkan. Penyelenggaraan angkutan udara perintis di Indonesia dilaksanakan dengan menggunakan acuan Peraturan Menteri Perhubungan Nomor PM 79 Tahun 2017 tentang Kriteria dan Penyelenggaraan Kegiatan Angkutan Udara Perintis dan Subsidi Angkutan Udara Kargo. Pada peraturan ini penyelenggaraan angkutan udara perintis dibedakan menjadi angkutan udara perintis kargo dan penumpang.

Tujuan paling penting penyelenggaraan angkutan udara perintis adalah untuk menekan kesenjangan harga komoditas akibat biaya logistik yang tinggi (Yuliana dkk., 2018) dan menjamin aksesibilitas masyarakat (Yarlina dan Lindasari, 2015). Berdasarkan kajian yang dilakukan oleh Yuliana dkk. (2018) penyelenggaraan angkutan udara perintis kargo diprioritaskan untuk daerah - daerah tertentu dengan mempertimbangkan kesesuaian tipe pesawat, karakteristik lapangan terbang, pola subsidi yang tepat untuk menjamin penurunan kesenjangan harga serta mekanisme pelaksanaan dan pengawasan program angkutan udara perintis. Angkutan udara perintis juga sangat diperlukan untuk menjamin aksesibilitas masyarakat (Yarlina dan Lindasari, 2015). Berdasarkan penelitian ini, strategi yang paling sesuai untuk pengembangan daerah adalah dengan meningkatkan potensi sumber daya alam dan pariwisata. Potensi tersebut dapat dikembangkan dengan baik dengan dukungan transportasi yang baik, khususnya transportasi udara.

Angkutan udara perintis diselenggarakan oleh pemerintah dan pelaksanaannya dilakukan oleh badan usaha angkutan udara niaga nasional berdasarkan perjanjian dengan pemerintah. Dalam penyelenggaraan angkutan udara perintis, pemerintah daerah wajib menjamin tersedianya lahan, prasarana angkutan udara, keselamatan dan keamanan penerbangan, serta kompensasi lainnya. Angkutan udara perintis dilaksanakan secara terpadu dengan sektor lain berdasarkan pendekatan pembangunan wilayah.

Jumlah rute yang telah dilaksanakan, alokasi anggaran dan realisasi untuk angkutan udara perintis pada periode tahun 2015 - 2017 dapat dilihat pada Tabel 2. Dapat dilihat bahwa jumlah rute berkurang, namun jumlah anggaran semakin meningkat. 
Tabel 2. Alokasi dan Realisasi Anggaran Angkutan Udara Perintis

\begin{tabular}{|c|c|r|r|}
\hline Tahun & Jumlah Rute & Alokasi Anggaran (Rp) & Realisasi Anggaran (Rp) \\
\hline 2015 & 214 & 489.913 .000 & 402.789 .000 \\
\hline 2016 & 209 & 548.211 .000 & 489.336 .000 \\
\hline 2017 & 184 & 632.209 .000 & 632.209 .000 \\
\hline
\end{tabular}

Sumber : KP 403/18, 2018

Angkutan udara perintis adalah salah satu kegiatan yang pembiayaannya berasal dari subsidi pemerintah, sehingga perlu dilaksanakan evaluasi terkait penyelenggaraan dan kondisi di lapangan untuk menjamin bahwa anggaran tersebut tepat sasaran. Pakan (2013) melakukan penelitian di Maluku Utara yang difokuskan kepada permasalahan yang terjadi di lapangan dan realisasi pada tahun anggaran 2012. Permasalahan pada penerbangan perintis di Maluku Utara adalah adanya campur tangan Pemerintah Daerah dalam pengoperasian penerbangan perintis yaitu dengan melaksanakan kerjasama dengan maskapai komersial dan menentukan tarif penerbangan, sedangkan dalam Undang - Undang No. 1 Tahun 2009 tentang Penerbangan jelas dinyatakan pada Pasal 104 sampai dengan Pasal 106 bahwa penerbangan perintis adalah tanggung jawab pemerintah pusat baik dalam menentukan rute, maskapai yang beroperasi, frekuensi penerbangan, maupun perhitungan tarif.

Yarlina dan Lindasari (2015) melakukan evaluasi ketersediaan sarana dan prasarana angkutan udara di Kabupaten Kapuas Hulu. Tujuannya untuk memberikan rekomendasi untuk pengembangan pelayanan angkutan udara di daerah perbatasan. Dari hasil analisis didapatkan bahwa untuk keperluan konektivitas pada angkutan udara perbatasan lebih ditekankan kepada pelayanan yang cepat dengan aksesibilitas yang mudah, baik pada fasilitas sisi udara maupun sisi darat. Kapasitas yang dimaksud meliputi fasilitas yang tersedia saat ini untuk operasi pesawat yang ada dan kemungkinan pengembangannya.

\section{METODE PENELITIAN}

Metode penelitian yang digunakan adalah metode kualitatif studi kasus. Metode ini digunakan karena paling sesuai dengan pertanyaan penelitian mengenai "how" yaitu bagaimanakah perkembangan yang terjadi pada angkutan udara rute Sumenep - Surabaya pp. dan "why" yaitu tentang mengapa angkutan udara rute Sumenep - Surabaya pp. dapat mengalami perkembangan dari perintis menjadi komersial. Permasalahan perkembangan angkutan udara rute Sumenep - Surabaya pp. merupakan obyek penelitian yang bersifat kontemporer yaitu permasalahan yang sedang terjadi saat ini dan masih memiliki dampak yang dapat dirasakan pada saat penelitian dilaksanakan. Pelaksanaan penelitian menggunakan pendekatan naturalistik di mana penelitian dilaksanakan pada lokasi dan kondisi sebenarnya yaitu di Bandar Udara Trunojoyo - Sumenep untuk mengetahui pelaksanaan, individu individu yang terlibat, permasalahan yang terjadi dan keberhasilan atau kegagalan pelaksanaan angkutan udara rute Sumenep - Surabaya pp. Penelitian yang dilakukan pada kondisi alamiah ini peneliti tidak mempunyai kemampuan untuk mengontrol kondisi lingkungan.

Metode analisis untuk mengidentifikasi faktor - faktor yang mempengaruhi perkembangan angkutan udara rute Sumenep - Surabaya pp. dilakukan dengan menggunakan kategorisasi. Kategorisasi dilakukan dengan mengumpulkan fakta sejenis yang didapatkan dari data primer yaitu wawancara dan observasi serta data sekunder yaitu dokumen dan data (Moleong, 2018). Tujuan dari kategorisasi ini adalah untuk mendapatkan gambaran yang lebih umum berdasarkan berbagai variasi dan bentuk data. Fakta - fakta sejenis tersebut berupa kata - kata kunci yang kemudian dikelompokkan ke dalam sub tema. Sub - tema tersebut kemudian dikelompokkan lagi menjadi tema - tema yang menjadi faktor - faktor yang mempengaruhi perkembangan angkutan udara rute Sumenep - Surabaya pp. 


\section{PENGUMPULAN DATA}

Pengumpulan data primer dilakukan dengan wawancara dan observasi. Pemilihan informan menggunakan purposive sampling untuk menentukan tokoh kunci yang akan diwawancarai. Informan yang dipilih tidak menggambarkan populasi, tetapi lebih diutamakan kepada informasi yang ingin didapatkan. Wawancara dilaksanakan dengan berpedoman kepada panduan yang berisi pertanyaan - pertanyaan terbuka terkait dengan angkutan udara rute Sumenep - Surabaya pp. Untuk mengetahui faktor - faktor yang mempengaruhi perkembangan angkutan udara rute Sumenep - Surabaya pp. dilakukan wawancara dengan 1 informan dari Kantor Otoritas Bandar Udara Wilayah III, 2 orang informan dari Unit Penyelenggara Bandar Udara Trunojoyo, 1 orang informan dari Dinas Perhubungan Kabupaten Sumenep. Informasi tentang operasional penerbangan dan hambatan selama pelaksanaan pelayanan angkutan udara didapatkan dari informan operator penerbangan. Informasi yang berkaitan dengan karakteristik perjalanan dan latar belakang penggunaan angkutan udara diperoleh dari 15 informan penumpang angkutan udara rute Sumenep - Surabaya pp. Sebagai tambahan informasi digunakan data sekunder. Pengumpulan data sekunder berupa dokumen, peraturan dan hasil survei yang berkaitan dengan pelaksanaan angkutan udara rute Sumenep - Surabaya pp. yang didapatkan dari pihak - pihak terkait pelaksanaan angkutan udara rute Sumenep - Surabaya pp.

\section{ANALISIS PENELITIAN}

\section{Gambaran Umum Lokasi Penelitian}

Kabupaten Sumenep adalah salah satu kabupaten di Pulau Madura yang berjarak kurang lebih 166 km dari Surabaya, ibu kota Provinsi Jawa Timur. Wilayah Kabupaten Sumenep berada di ujung timur Pulau Madura yang terletak diantara 113032'54" - 116 $16^{0} 6^{\prime} 48^{\prime \prime}$ Bujur Timur dan $4^{0} 55^{\prime}-7^{0} 24^{\prime}$ Lintang Selatan, dengan batas - batas sebelah Utara Laut Jawa, sebelah Timur Laut Jawa dan Laut Flores, sebelah Selatan Selat Madura, sebelah Barat Kabupaten Pamekasan. Luas wilayah Kabupaten Sumenep adalah 2.093,47 km² yang terbagi menjadi 25 kecamatan dan 334 desa. Penduduk di Kabupaten Sumenep pada tahun 2018 mencapai 1.085.227 jiwa. Namun, potensi wilayah dan penduduk ini belum mampu dimanfaatkan untuk meningkatkan taraf hidup masyarakatnya. Jumlah penduduk Kabupaten Sumenep sejumlah 19,62\% masih berada di bawah garis kemiskinan (Badan Pusat Statistik, 2020). Persentase tersebut lebih tinggi jika dibandingkan dengan angka kemiskinan rata - rata Povinsi Jawa Timur yaitu sebesar $11,77 \%$.

Pada awalnya akses dari dan ke Pulau Madura hanya dapat menggunakan kapal penyeberangan, hingga kemudian dibangun Jembatan Suramadu pada tahun 2009 yang memungkinkan akses melalui darat secara langsung. Rute Sumenep - Surabaya pp. dapat dilihat pada Gambar 1. Selain konektivitas jalur darat, konektivitas jalur udara juga dikembangkan. Hal ini dilakukan mengingat Kabupaten Sumenep sudah mempunyai infrastruktur utama angkutan udara yaitu Bandar Udara Trunojoyo yang belum dimanfaatkan secara maksimal. Tujuan utama dari pembangunan infrastruktur adalah untuk memenuhi tujuan tertentu sesuai dengan fungsi infrastruktur tersebut (Suprayitno \& Soemitro, 2018). Pembangunan bandar udara bertujuan untuk melayani angkutan udara. Untuk memenuhi tujuan tersebut, maka dilakukan upaya oleh Pemerintah Daerah. Sebagai langkah awal Pemerintah Daerah Kabupaten Sumenep mengusulkan rute Sumenep - Surabaya pp. sebagai rute angkutan udara perintis. Dasar pengusulan ini adalah rute Sumenep - Surabaya ditinjau secara komersial belum menghasilkan. Rute ini ditetapkan sebagai rute perintis oleh Kementerian Perhubungan pada tahun 2015. Rute lain yang ditetapkan sebagai rute perintis untuk Koordinator Wilayah Sumenep pada tahun 2015 adalah Surabaya - Bawean pp., Surabaya - Karimunjawa pp. dan Sumenep - Jember pp. 


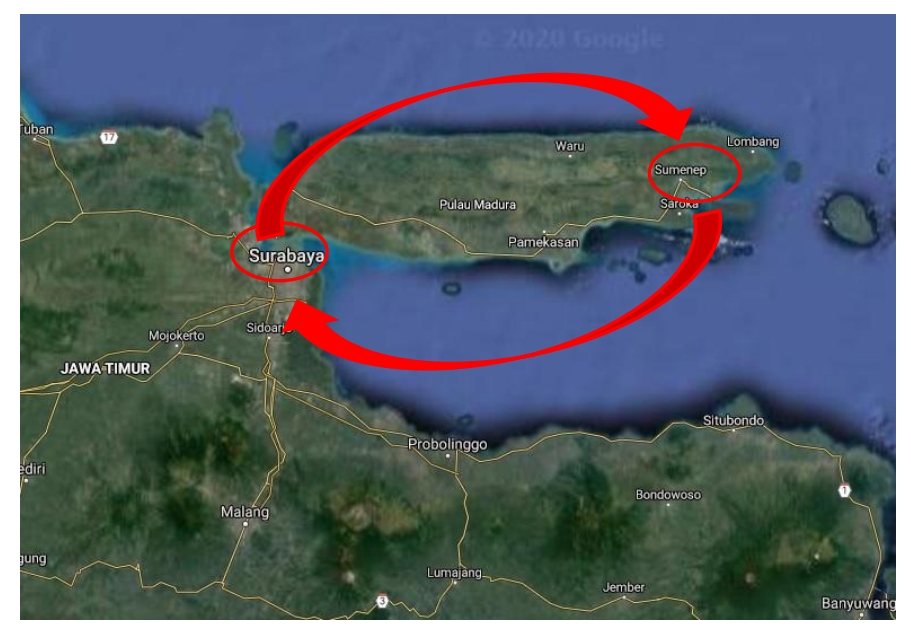

Gambar 1. Rute Sumenep - Surabaya pp.

Prasarana angkutan udara di Kabupaten Sumenep adalah Bandar Udara Trunojoyo. Peran Bandar Udara Trunojoyo adalah sebagai simpul jaringan transportasi, gerbang ekonomi, alih moda transportasi, perindustrian, perdagangan, pariwisata dan wawasan nusantara. Fungsinya adalah untuk pemerintahan dan pengusahaan. Penggunaan bandara saat ini adalah untuk penerbangan domestik dengan hierarki sebagai bandara pengumpan dan mempunyai klasifikasi 3C. Data umum terkait sarana dan prasarana di Bandar Udara Trunojoyo - Sumenep dapat dilihat pada Tabel 3.

Tabel 3. Data Umum Bandar Udara Trunojoyo

\begin{tabular}{|l|l|}
\hline \multicolumn{1}{|c|}{ Uraian } & \multicolumn{1}{c|}{ Keterangan } \\
\hline Kode ICAO & WART \\
\hline Kode IATA & SUP \\
\hline Kategori Bandara & Domestik \\
\hline Kelas Bandara & III \\
\hline Critical Aircraft & ATR 72 \\
\hline Fasilitas Alih Moda & Taxi \\
\hline Luas Lahan & $320.000 \mathrm{~m}^{2}$ \\
\hline Runway & $1.600 \mathrm{~m} \mathrm{x} 30 \mathrm{~m}$ \\
\hline Apron & A : $40 \mathrm{~m} \times 40 \mathrm{~m} ; \mathrm{B}: 75 \mathrm{~m} \times 80 \mathrm{~m}$ \\
\hline Taxiway & $\mathrm{A}: 40 \mathrm{~m} \times 10 \mathrm{~m} ; \mathrm{B}: 75 \mathrm{~m} \mathrm{x} 15 \mathrm{~m}$ \\
\hline Terminal Penumpang & $132 \mathrm{~m}^{2}$ \\
\hline Terminal Kargo & Tidak ada \\
\hline Sumber $:$ Kantor UPBU Trunojoyo, 2019 \\
\hline
\end{tabular}

\section{Perkembangan Angkutan Udara Rute Sumenep - Surabaya pp.}

Perkembangan yang terjadi selama periode pelayanan angkutan udara rute Sumenep Surabaya pp. dapat dibedakan menadi periode sebelum tahun 2015 dan periode tahun 2015 2019. Periode sebelum tahun 2015 merupakan periode peningkatan prasarana bandara. Pada periode ini Bandar Udara Trunojoyo hanya dimanfaatkan untuk sekolah penerbangan. Sesuai dengan teori Ashford (2011) prasarana bandar udara mempengaruhi jenis pesawat yang beroperasi, maka sangat penting untuk menyiapkan prasarana di Bandar Udara Trunojoyo agar dapat digunakan untuk melayani penerbangan pesawat penumpang. Pada periode ini aktivitas lebih diprioritaskan untuk meningkatkan dan melengkapi fasilitas Bandar Udara Trunojoyo. 
Prasarana bandar udara telah memenuhi persyaratan teknis untuk digunakan pesawat jenis propeller dengan kapasitas 12 - 15 penumpang. Pada awalnya rute Sumenep - Surabaya pp. dilayani oleh angkutan udara perintis. Hal ini karena spesifikasi teknis bandar udara dan kondisi pasar belum memungkinkan untuk dilayani angkutan udara komersial. Frekuensi penerbangan yang dijadwalkan adalah 2 kali penerbangan dalam 1 minggu. Setelah dilayani oleh angkutan udara perintis selama 2 tahun, mulai tercipta pasar bagi pelayanan angkutan udara rute Sumenep - Surabaya pp. yang ditandai dengan semakin meningkatnya jumlah penumpang. Pada dasarnya tujuan utama pengembangan rute adalah untuk mendorong maskapai baru mengoperasikan rute baru di suatu bandara (Halpern dan Graham, 2015). Agar rute penerbangan dapat berkembang, diperlukan suatu proses yang harus dilakukan oleh pengelola bandar udara. Menurut Halpern dan Graham (2016) tahap pertama pengembangan rute adalah menentukan tujuan. Pengelola bandara dan pemerintah daerah mempunyai tujuan agar rute perintis dapat berkembang menjadi komersial. Namun karena fasilitas bandar udara belum memenuhi persyaratan teknis untuk operasional pesawat komersial, kemudian dilakukan peningkatan prasarana bandara. Peningkatan prasarana bandara dilakukan dengan memperpanjang dan memperlebar runway, penambahan apron serta taxiway.

Pasar yang telah tercipta dan fasilitas bandar udara yang telah memenuhi persyaratan secara teknis kemudian menarik minat operator angkutan udara komersial untuk melayani rute Sumenep - Surabaya pp. Proses persetujuan operasional angkutan udara komersial dikeluarkan oleh Kemenhub dan angkutan udara komersial mulai beroperasi pada bulan September 2017. Karena angkutan udara komersial sudah beroperasi, maka sesuai dengan PM 79 tahun 2017 pelayanan angkutan udara perintis untuk rute Sumenep - Surabaya pp. dihentikan. Dengan demikian angkutan udara rute Sumenep - Surabaya pp. merupakan rute perintis yang telah berhasil berkembang menjadi rute komersial. Pelayanan angkutan udara komersial frekuensi dan jadwal penerbangannya lebih teratur jika dibandingkan dengan angkutan udara perintis, yaitu 1 kali per hari. Jumlah penumpang dan penerbangan juga mengalami peningkatan jika dibandingkan dengan ketika dilayani oleh angkutan udara perintis.

\section{Faktor - Faktor yang Mempengaruhi Perkembangan Angkutan Udara Rute Sumenep - Surabaya pp.}

Berdasarkan hasil wawancara dan observasi di lapangan didapatkan unit - unit informasi yang kemudian dikategorisasikan ke dalam sub tema dan tema. Secara rinci pengakategorian unit informasi menjadi sub tema dapat dilihat pada Tabel 4. Fakta - fakta sejenis dikumpulkan dari setiap unit informasi kemudian dikelompokkan menjadi 31 sub tema. 
Tabel 4. Kategorisasi Unit Informasi menjadi Sub Tema Faktor - Faktor Yang Mempengaruhi Perkembangan Rute Sumenep - Surabaya pp.

\begin{tabular}{|c|c|}
\hline Unit Informasi & Sub Tema \\
\hline $\begin{array}{l}\text { keberangkatan haji, kunjungan pejabat, sekolah penerbangan, angkutan } \\
\text { perintis, angkutan komersial }\end{array}$ & 1. Penggunaan Bandar Udara \\
\hline Pemerintah Daerah, satuan kerja, Kementerian Perhubungan & 2. Pengelolaan Bandar Udara \\
\hline perpanjangan runway, apron baru, taxiway baru, perluasan terminal & 3. Kondisi Prasarana Bandar Udara \\
\hline $\begin{array}{l}\text { panjang runway terbatas, persiapan teknis belum selesai, penerbangan } \\
\text { komersial ditunda, perpanjangan runway terhambat obstacle }\end{array}$ & 4. Permasalahan Komersialisasi \\
\hline APBD, APBN, pembebasan lahan & 5. Dukungan Anggaran \\
\hline $\begin{array}{l}\text { promosi, insentif, studi banding, pengusulan rute perintis, koordinasi, } \\
\text { surat edaran, sosialisasi }\end{array}$ & 6. Dukungan Kebijakan \\
\hline pengurusan slot, taksi bandara & 7. Dukungan Operasional \\
\hline analisis pasar, perhitungan harga tiket, promosi & 8. Operator Penerbangan Komersial \\
\hline permasalahan lelang, permasalahan operasional & 9. Permasalahan Angkutan Udara Perintis \\
\hline $\begin{array}{l}\text { Cessna Caravan 208B, Twin Otter DHC6-300, } 12 \text { penumpang, } 15 \\
\text { penumpang }\end{array}$ & 10. Jenis dan Kapasitas Pesawat Perintis \\
\hline 2 kali per minggu, frekuensi sesuai target & 11. Frekuensi Perintis \\
\hline hari - hari tertentu, tidak setiap hari & 12. Jadwal Perintis \\
\hline mahal, ditentukan pemerintah, usulan Dinas Perhubungan & 13. Harga Tiket Perintis \\
\hline kurang praktis, beli di kantor perwakilan, harus telepon & 14. Pembelian Tiket Perintis \\
\hline $\begin{array}{l}\text { Terlambat, belum ada penerbangan komersial, perintis harus tetap } \\
\text { jalan, diusulkan kembali sebagai rute perintis, pengurangan rute karena } \\
\text { masukny a komersial, perintis dihapus, mengubah penetapan perintis }\end{array}$ & 15. Pelaksanaan Angkutan Perintis \\
\hline $\begin{array}{l}\text { Jumlah penumpang meny esuaikan MTOW, jumlah seat } 12 \text { diisi } 11 \text {, } \\
\text { jadwal perawatan pesawat, penundaan penerbangan karena cuaca }\end{array}$ & 16. Keselamatan Penerbangan \\
\hline Rendahny a load factor, load factor rendah & 17. Load Factor Rendah \\
\hline $\begin{array}{l}\text { Jumlah penumpang tidak sesuai target, kurang, realisasi tidak sesuai } \\
\text { target }\end{array}$ & 18. Jumlah Penumpang Perintis \\
\hline Susi Air, Airfast & 19. Operator Perintis \\
\hline $\begin{array}{l}\text { masa kontrak } 1 \text { tahun, pembay aran per bulan, tergantung realisasi } \\
\text { penerbangan, harga tetap }\end{array}$ & 20. Kontrak Angkutan Perintis \\
\hline $\begin{array}{l}\text { Setiap hari, bukan prime time, perlu disesuaikan, harus bermalam, } \\
\text { langsung kembali, survei perubahan jadwal }\end{array}$ & 21. Jadwal Komersial \\
\hline 1 kali per hari, 2 kali per hari, kembali ke 1 kali per hari & 22. Frekuensi Komersial \\
\hline ATR 72,72 penumpang & 23. Jenis dan Kapasitas Pesawat Komersial \\
\hline $\begin{array}{l}\text { load factor di atas } 50 \% \text {, load factor rata - rata tinggi, load factor } \\
\text { tidak boleh di bawah } 20 \%\end{array}$ & 24. Load Factor Komersial \\
\hline tiket murah, sangat terjangkau & 25. Harga Tiket Komersial \\
\hline $\begin{array}{l}\text { penump ang luber-luber, pagi penumpang kosong, penumpang } \\
\text { terendah bulan Desember, penumpang anjlok, jumlah penumpang } \\
\text { turun, kurangny a penumpang }\end{array}$ & 26. Jumlah Penumpang Komersial \\
\hline $\begin{array}{l}\text { pagi penumpang kosong, jadwal tidak tepat, kurang promosi, } \\
\text { seminggu terbang cuma } 4 \text { kali, accident Lion Air }\end{array}$ & 27. Permasalahan Komersial \\
\hline $\begin{array}{l}\text { demand kurang, perawatan pesawat, faktor cuaca, reschedule, } \\
\text { pembatalan mendadak, dipindah hari berikutnya, kadang delay dan } \\
\text { cancel, refund }\end{array}$ & 28. Pembatalan dan Penundaan Penerbangan \\
\hline beliny a sudah tiket terusan, tiketny a ny ambung, tiketny a terusan & 29. Penggunaan Tiket Terusan \\
\hline pilih transit, tunggu di bandara & 30. Penumpang Transit \\
\hline $\begin{array}{l}\text { melay ani angkut an barang, bagasi berbay ar, bawa bagasi bany ak, } \\
\text { bay ar mahal }\end{array}$ & 31. Bagasi Berbay ar \\
\hline
\end{tabular}


Sub tema - sub tema tersebut kemudian dikategorisasikan lagi ke dalam tema - tema yang lebih umum. Kategorisasi tersebut dapat dilihat pada Tabel 5.

Tabel 5. Kategorisasi Sub Tema menjadi Tema Faktor - Faktor Yang Mempengaruhi Perkembangan Rute Sumenep - Surabaya pp.

\begin{tabular}{|c|c|}
\hline Sub Tema & Tema \\
\hline 1. Penggunaan Bandar Udara & \multirow{3}{*}{ 1. Fasilitas Bandar Udara } \\
\hline 2. Pengelolaan Bandar Udara & \\
\hline 3. Kondisi Prasarana Bandar Udara & \\
\hline 5. Dukungan Anggaran & \multirow{3}{*}{ 2. Dukungan Pemerintah } \\
\hline 6. Dukungan Kebijakan & \\
\hline 7. Dukungan Operasional & \\
\hline 4. Permasalahan Komersialisasi & \multirow{9}{*}{ 3. Operator Penerbangan yang Beroperasi } \\
\hline 8. Operator Penerbangan Komersial & \\
\hline 9. Permasalahan Angkutan Udara Perintis & \\
\hline 15. Pelaksanaan Angkutan Udara Perintis & \\
\hline 16. Keselamatan Penerbangan & \\
\hline 19. Operator Penerbangan Perintis & \\
\hline 20. Kontrak Angkutan Perintis & \\
\hline 27. Permaslahan Komersial & \\
\hline 31. Bagasi Berbayar & \\
\hline 10. Jenis dan Kapasitas Pesawat Perintis & \multirow{6}{*}{ 4. Jumlah Penumpang } \\
\hline 17. Load Factor Perintis & \\
\hline 18. Jumlah Penumpang Perintis & \\
\hline 23. Jenis dan Kapasitas Pesawat Komersial & \\
\hline 24. Load Factor Komersial & \\
\hline 26. Jumlah Penumpang Komersial & \\
\hline 11. Frekuensi Perintis & \multirow{5}{*}{ 5. Jadwal dan Frekuensi Penerbangan } \\
\hline 12. Jadwal Perintis & \\
\hline 21. Jadwal Komersial & \\
\hline 22. Frekuensi Komersial & \\
\hline 28. Pembatalan dan Penundaan Penerbangan & \\
\hline 13. Harga Tiket Perintis & \multirow{3}{*}{ 6. Harga Tiket } \\
\hline 14. Pembelian Tiket Perintis & \\
\hline 25. Harga Tiket Komersial & \\
\hline 29. Penggunaan Tiket Terusan & \multirow{2}{*}{ 7. Keterhubungan Rute } \\
\hline 30. Penumpang Transit & \\
\hline
\end{tabular}

Berdasarkan kategorisasi didapatkan tema umum yang merupakan faktor - faktor yang mempengaruhi perkembangan angkutan udara rute Sumenep - Surabaya pp. Faktor - faktor tersebut dapat diuraikan pada penjelasan di bawah ini.

1. Fasilitas Bandar Udara

Runway Bandar Udara Trunojoyo pada awalnya mempunyai dimensi $950 \mathrm{~m}$ x $23 \mathrm{~m}$, pada tahun 2012 ditingkatkan panjangnya menjadi $1.160 \mathrm{~m}$ x $23 \mathrm{~m}$. Pada tahun 2016 ditingkatkan lagi panjangnya menjadi $1.600 \mathrm{~m}$ dan lebarnya ditambah menjadi $30 \mathrm{~m}$. Dimensi runway ini bertahan hingga pada kondisi eksisting di tahun 2019. Perkembangan panjang dan lebar runway 
di Bandar Udara Trunojoyo dapat dilihat Gambar 2. Pada tahap pengembangan runway dapat dilihat bahwa perkembangan yang paling pesat terjadi pada tahun 2016 di mana runway Bandar Udara Trunojoyo diperpanjang dan diperlebar. Pengembangan runway sangat diperlukan agar dapat digunakan untuk mengakomodir pesawat udara yang lebih besar.

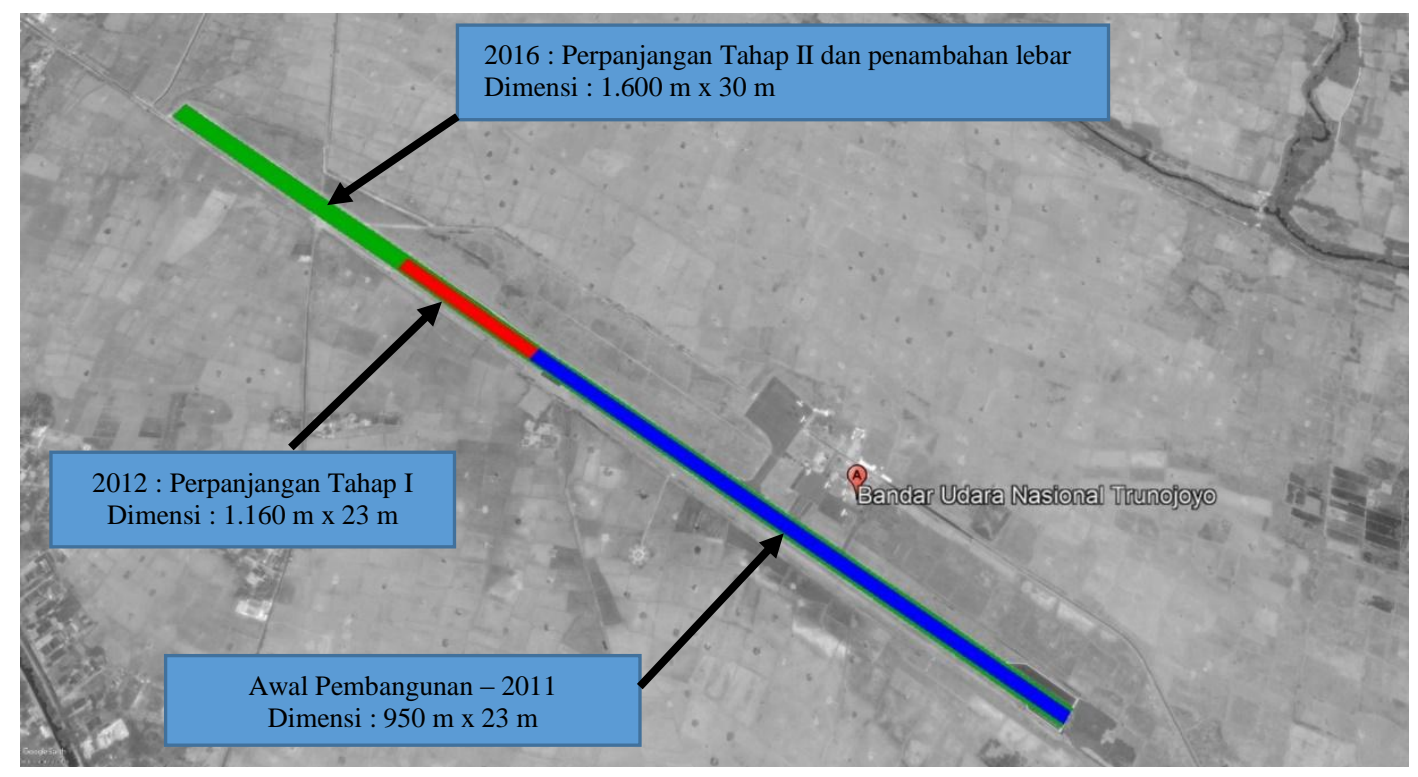

Gambar 2. Perkembangan Panjang Runway

Pada awal pembangunan sampai dengan tahun 2015, fasilitas taxiway hanya ada 1 yaitu taxiway Alpha dengan ukuran $40 \mathrm{~m}$ x $10 \mathrm{~m}$. Kemudian pada tahun 2016 dibuat taxiway baru yaitu taxiway Bravo dengan ukuran 75 m x 15 m. Dengan demikian jumlah taxiway di Bandar Udara Trunojoyo mengalami perkembangan dari semula 1 menjadi 2 taxiway. Kondisi ini tidak berubah sampai dengan tahun 2019. Perkembangan taxiway dapat dilihat pada Gambar 3.
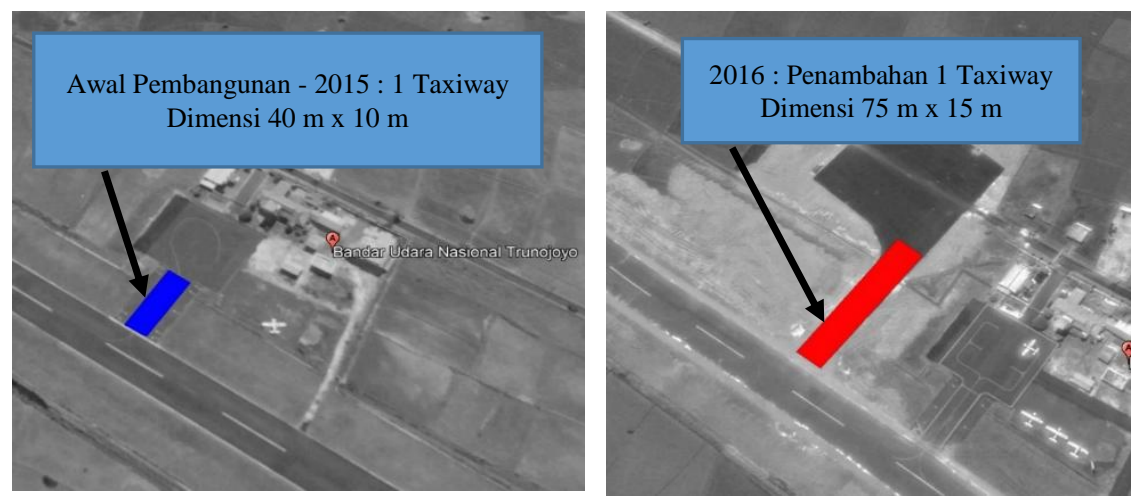

Gambar 3. Perkembangan Taxiway

Fasilitas apron dari awal pembangunan hingga tahun 2015 sejumlah 1 apron dengan ukuran $40 \mathrm{~m}$ x $40 \mathrm{~m}$. Selanjutnya terjadi penambahan 1 buah apron pada tahun 2016 dengan ukuran $75 \mathrm{~m}$ x $80 \mathrm{~m}$. Kondisi eksisting tahun 2019 adalah 2 buah apron. Perkembangan yang terjadi dari semula 1 apron bertambah menjadi 2 apron seperti terlihat pada Gambar 4.

Fasilitas terminal penumpang pada awal pembangunan hingga tahun 2017 mempunyai luas total $300 \mathrm{~m}^{2}$. Pada tahun 2018 untuk mengakomodir peningkatan jumlah penumpang yang terjadi luas total terminal penumpang ditambah menjadi $480 \mathrm{~m}^{2}$. Luas ini bertahan hingga kondisi eksisiting tahun 2019. 
Fasilitas lain yang mengalami perkembangan adalah fasilitas angkutan pemadu moda. Pada awalnya belum tersedia angkutan pemadu moda di Bandar Udara Trunojoyo, angkutan untuk pengguna bandara didominasi oleh kendaraan pribadi. Pada tahun 2018 mulai beroperasi pelayanan taksi bandara sebagai salah satu upaya untuk memberikan fasilitas angkutan pemadu moda bagi penumpang pesawat udara di Bandar Udara Trunojoyo.

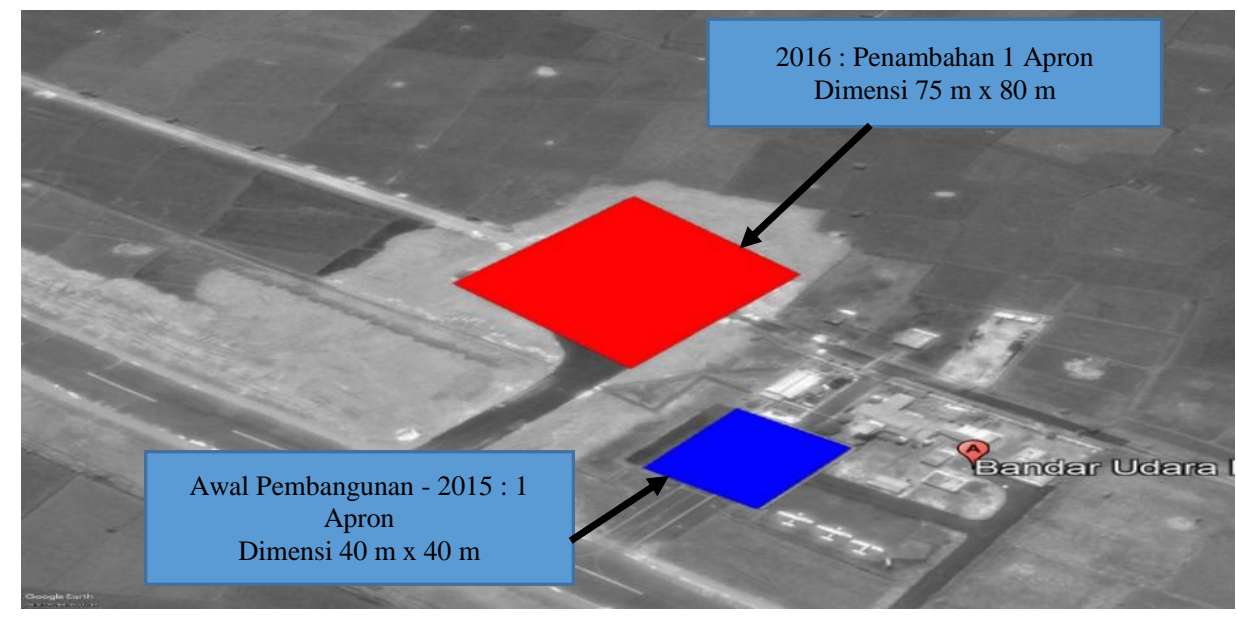

Gambar 4. Perkembangan Apron

Perkembangan fasilitas yang ada di Bandar Udara Trunojoyo sangat berpengaruh pada perkembangan rute Sumenep - Surabaya pp. Pada awalnya fasilitas bandar udara terbatas, dengan runway yang pendek sehingga belum ada penerbangan pesawat yang mengangkut penumpang. Setelah fasilitas ditingkatkan dan dilengkapi, maka mulai masuk penerbangan angkutan udara perintis penumpang yang kemudian berkembang menjadi angkutan udara komersial.

\section{Dukungan Pemerintah}

Faktor yang tidak kalah penting adalah dukungan pemerintah. Pemerintah pusat memberikan dukungan berupa anggaran peningkatan fasilitas bandar udara dan subsidi angkutan udara perintis. Pemerintah daerah memberikan dukungan dengan menyediakan anggaran untuk penyediaan lahan yang diperluka dalam proses peningkatan fasilitas bandar udara. Dukungan lain berkaitan dengan pengelolaan bandara. Menurut Soemitro dan Suprayitno (2018) organisasi pengelola fasilitas merupakan salah satu faktor dasar bagi terjaminnya kualitas fasilitas. Fasilitas dalam hal ini adalah fasilitas di Bandar Udara Trunojoyo. Pada awalnya Bandar Udara Trunojoyo dikelola oleh Pemerintah Daerah Kabupaten Sumenep di mana kelas bandara masih berstatus sebagai satuan kerja. Pada perkembangannya pengelolaannya diserahkan kepada Kementerian Perhubungan menjadi bandara yang dikelola oleh Unit Pelaksana Bandar Udara Kementerian Perhubungan dan meningkat kelasnya menjadi kelas III.

\section{Operator Penerbangan yang Beroperasi}

Operator penerbangan yang ada juga mengalami perkembangan di mana sebelumnya hanya berasal dari general aviation yaitu sekolah penerbangan kemudian berkembang menjadi dilayani oleh operator yang merupakan Badan Usaha Angkutan Udara Niaga. Dengan berkembangnya operator penerbangan yang melayani rute Sumenep - Surabaya pp. jenis pesawat juga berkembang menjadi pesawat yang berukuran lebih besar dan kapasitas penumpang lebih banyak. Kapasitas angkutan udara perintis pada awalnya hanya 12 penumpang kemudian ketika operator penerbangan berganti, digunakan pesawat dengan kapasitas lebih banyak yaitu 15 penumpang pada tahun 2016 dan 2017. Ketika terjadi pergantian dari angkutan udara perintis ke komersial, jenis pesawat yang digunakan juga 
berubah menjadi pesawat yang lebih besar dengan kapasitas penumpang lebih banyak yaitu 72 penumpang. Perkembangan jenis penerbangan dapat dilihat pada Tabel 6 .

Pada awalnya perkembangannya angkutan udara rute ini belum dioperasikan karena belum ada operator penerbangan yang tertarik untuk menjalankan. Pemerintah Daerah Kabupaten Sumenep melakukan upaya untuk mengembangkan rute dengan mengusulkan sebagai rute angkutan udara perintis. Setelah angkutan udara perintis beroperasi, dapat diketahui bahwa potensi penumpang untuk rute ini ada sehingga kemudian ada operator penerbangan komersial yang bersedia melayani rute ini.

Tabel 6. Perkembangan Jenis Penerbangan

\begin{tabular}{|c|l|l|l|c|}
\hline Tahun & $\begin{array}{l}\text { Jenis } \\
\text { Pene rbangan }\end{array}$ & $\begin{array}{l}\text { Operator } \\
\text { Penerbangan }\end{array}$ & Jenis Pesawat & $\begin{array}{c}\text { Kapasitas } \\
\text { Penumpang }\end{array}$ \\
\hline Sebelum 2015 & $\begin{array}{l}\text { General } \\
\text { Aviation }\end{array}$ & $\begin{array}{l}\text { Sekolah } \\
\text { Penerbangan }\end{array}$ & Cessna 172 & 0 \\
\hline 2015 & Perintis & Susi Air & Cessna 208B & 12 \\
\hline 2016 & Perintis & Airfast Indonesia & Twin Otter DHC6-300 & 15 \\
\hline 2017 & Perintis & Airfast Indonesia & Twin Otter DHC6-300 & 15 \\
\hline 2018 & Komersial & Wings Air & ATR 72 & 72 \\
\hline 2019 & Komersial & Wings Air & ATR 72 & 72 \\
\hline
\end{tabular}

\section{Jumlah Penumpang}

Jumlah penumpang adalah faktor penting yang mempengaruhi perkembangan rute Sumenep - Surabaya pp. ditinjau dari sisi operator penerbangan. Untuk penerbangan angkutan udara perintis, faktor ini tidak terlalu signifikan karena operator mendapatkan subsidi dari pemerintah untuk operasional penerbangan. Hal ini sangat berbeda dengan operator angkutan udara komersial. Bagi operator penerbangan komersial, jumlah penumpang merupakan faktor utama yang dapat berpengaruh terhadap perkembangan angkutan udara. Biaya operasional peerbangan berasal dari penjualan tiket kepada penumpang. Operator penerbangan menentukan jumlah penumpang minimum untuk dapat melakukan penerbangan, sehingga jika jumlah penumpang di bawah jumlah minimum ini maka akan terjadi pembatalan penerbangan. Pembatalan penerbangan berdampak kepada menurunnya pelayanan operator penerbangan terhadap penumpang. Pada angkutan udara rute Sumenep - Surabaya pp. dapat dilihat bahwa pada awal penyelenggaraan jumlah penumpang banyak, sehingga operator menambah frekuensi penerbangannya. Namun kemudian ketika jumlah penumpang turun operator penerbangan melakukan pengurangan frekuensi penerbangan.

Jumlah penerbangan mengalami peningkatan pada periode tahun 2015 - 208 baik ketika dilayani oleh angkutan udara komersial. Peningkatan jumlah penerbangan ini mencapai puncaknya di tahun 2018, namun pada tahun 2019 jumlah penerbangan mengalami penurunan. Perkembangan jumlah penerbangan dapat dilihat pada Gambar 5. 


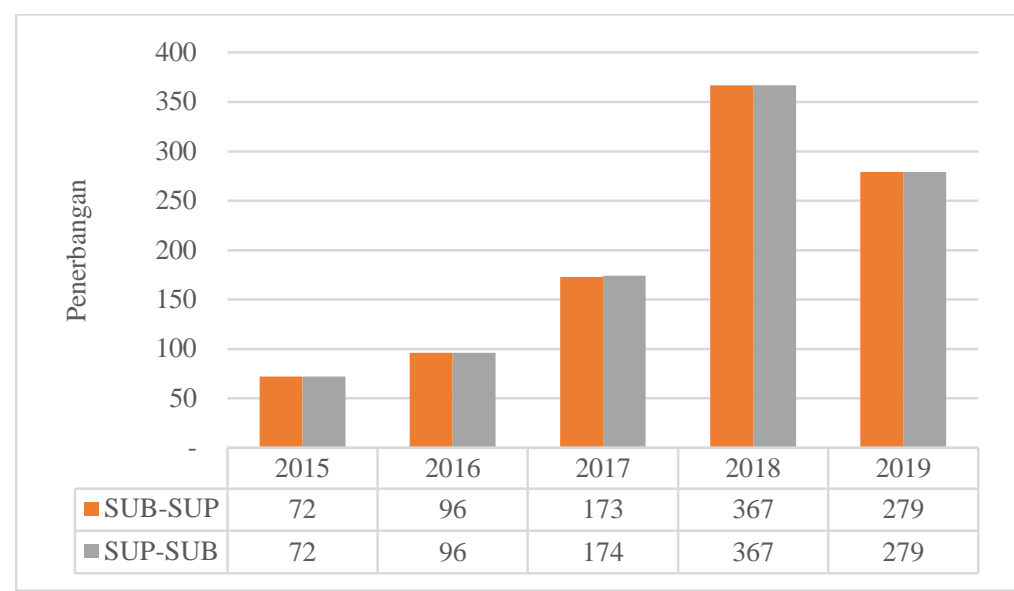

Gambar 5. Perkembangan Jumlah Penerbangan Rute Sumenep - Surabaya pp. (Sumber : Kantor UPBU Trunojoyo, 2019)

Perkembangan jumlah penumpang adalah terjadinya kenaikan pada periode tahun 2015 2018, kemudian mengalami penurunan di tahun 2019. Jumlah penumpang pada tahun 2018 merupakan yang tertinggi selama penyelenggaraan angkutan udara rute Sumenep - Surabaya. Perkembangan jumlah penumpang untuk rute Sumenep - Surabaya pp. dapat dilihat pada Gambar 6.

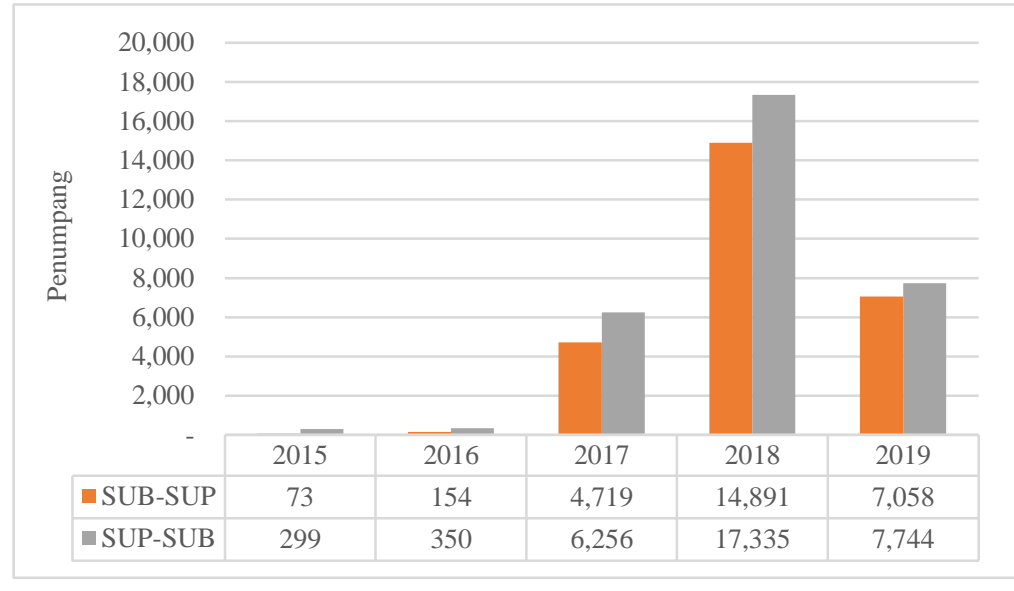

Gambar 6. Perkembangan Jumlah Penumpang Rute Sumenep - Surabaya pp.

(Sumber : Kantor UPBU Trunojoyo, 2019)

Load factor rata - rata rute Sumenep - Surabaya pp. juga mengalami perkembangan. Pada pelayanan angkutan udara perintis, load factor untuk rute Surabaya - Sumenep cenderung mengalami kenaikan, namun untuk rute Sumenep - Surabaya fluktuatif dengan terjadinya penurunan pada tahun 2016 kemudian naik lagi pada tahun 2017. Sedangkan load factor untuk angkutan udara komersial pada periode 2017 - 2019 cenderung mengalami penurunan. Perkembangan load factor rute Sumenep - Surabaya pp. dapat dilihat pada Tabel 7. 
Tabel 7. Load Factor Rata - Rata Angkutan Udara Rute Sumenep - Surabaya pp.

\begin{tabular}{|c|l|c|}
\hline \multicolumn{1}{|c|}{ Rute } & \multicolumn{1}{|c|}{ Tahun } & Load Factor (\%) \\
\hline \multirow{5}{*}{ Surabaya - Sumenep } & 2015 & 8,4 \\
\cline { 2 - 3 } & 2016 & 10,7 \\
\cline { 2 - 3 } & 2017 perintis & 11,4 \\
\cline { 2 - 3 } & 2017 komersial & 63,6 \\
\cline { 2 - 3 } Sumenep - Surabaya & 2018 & 56,1 \\
\hline & 2019 & 34,6 \\
\hline & 2015 & 34,6 \\
\hline & 2016 & 23,8 \\
\hline & 2017 perintis & 29,1 \\
\hline & 2017 komersial & 82,8 \\
\hline & 2018 & 65,5 \\
\hline & 2019 & 38 \\
\hline
\end{tabular}

\section{Jadwal dan Frekuensi Penerbangan}

Jadwal dan frekuensi penerbangan menjadi pertimbangan utama bagi penumpang untuk menggunakan angkutan udara rute Sumenep - Surabaya pp. Ketika dilayani angkutan udara perintis pada periode tahun 2015 sampai dengan 2017 jadwal penerbangan rute Sumenep Surabaya pp. belum teratur karena frekuensi penerbangan hanya 2 kali per minggu pada hari tertentu saja. Pada perkembangannya ketika dilayani oleh angkutan udara komersial jadwal menjadi lebih teratur yaitu setiap hari dengan frekuensi penerbangan 1 kali per hari. Pada tahun 2018 untuk periode summer 2 Mei s.d. 27 Oktober 2018, frekuensi penerbangan berubah menjadi 2 kali per hari, namun kemudian pada periode selanjutnya kembali berubah menjadi 1 kali per hari. Perkembangan jadwal dan penerbangan dapat dilihat pada Tabel 8. Jadwal dan frekuensi yang teratur telah menarik penumpang untuk menggunakan angkutan udara rute Sumenep - Surabaya pp. Hal ini dibuktikan dengan jumlah penumpang komersial yang mengalami kenaikan jika dibandingkan dengan saat dilayani angkutan udara perintis. Akan tetapi bagi penumpang, jadwal dan rute yang tersedia saat ini dirasakan belum sesuai dengan kebutuhannya. Sehingga rute Sumenep - Surabaya pp. akan dapat lebih dikembangkan dengan melakukan analisis terhadap kebutuhan penumpang. 
Tabel 8. Jadwal dan Frekuensi Penerbangan Rute Sumenep - Surabaya pp.

\begin{tabular}{|c|c|c|c|}
\hline \multirow[t]{2}{*}{ Rute } & \multirow{2}{*}{\begin{tabular}{|l|} 
Tahun \\
2015
\end{tabular}} & \multicolumn{2}{|c|}{ Frekuensi Penerbangan Jadwal Penerbangan } \\
\hline & & 2 kali per minggu & Sabtu, Minggu : 08.45 \\
\hline \multirow{6}{*}{ Surabaya - Sumenep } & 2016 & 2 kali per minggu & Rabu dan Jumat : 10.50 \\
\hline & 2017 perintis & 2 kali per minggu & Senin dan Rabu : 09.55 \\
\hline & 2017 komersial & 1 kali per hari & Setiap hari : 12.40 \\
\hline & 2018 & 1 kali per hari & Setiap hari : 12.40 \\
\hline & 2018 summer & 2 kali per hari & Setiap hari : 06. 30 dan 12.40 \\
\hline & 2019 & 1 kali per hari & Setiap hari : 12.45 \\
\hline \multirow{7}{*}{ Sumenep - Surabaya } & 2015 & 2 kali per minggu & Sabtu : 11.20; Minggu : 09.45 \\
\hline & 2016 & 2 kali per minggu & Selasa dan Kamis : 08.30 \\
\hline & 2017 perintis & 2 kali per minggu & Selasa dan Kamis : 08.00 \\
\hline & 2017 komersial & 1 kali per hari & Setiap hari : 13.45 \\
\hline & 2018 & 1 kali per hari & Setiap hari : 13.45 \\
\hline & 2018 summer & 2 kali per hari & Setiap hari : 07.40 dan 13.45 \\
\hline & 2019 & 1 kali per hari & Setiap hari : 13.45 \\
\hline
\end{tabular}

\section{Harga Tiket}

Harga tiket untuk rute Sumenep - Surabaya pp. mengalami perkembangan di mana ketika dilayani oleh angkutan udara perintis harga tiket masih relatif mahal dan ketersediaan serta informasi yang masih terbatas. Ketika dilayani angkutan udara komersial harga tiket lebih murah jika dibandingkan dengan angkutan udara perintis. Selain itu tiket angkutan udara komersial lebih mudah didapatkan jika dibandingkan dengan tiket angkutan udara perintis. Menurut penumpang harga tiket yang tersedia saat ini relatif murah dan menjadi salah satu pertimbangan dalam menggunakan moda transportasi udara. Perkembangan harga tiket dapat dilihat pada Tabel 9.

Tabel 9. Harga Tiket Angkutan Udara Rute Sumenep - Surabaya pp.

\begin{tabular}{|l|l|r|}
\hline Rute & Tahun & Harga Tiket \\
\hline \multirow{5}{*}{ Surabaya - Sumenep } & 2015 & 270.000 \\
\hline & 2016 & 307.700 \\
\cline { 2 - 3 } & 2017 perintis & 337.700 \\
\cline { 2 - 3 } Sumenep - Surabaya & 2017 komersial & $200.000-300.000$ \\
\hline & 2018 & $200.000-300.000$ \\
\hline & 2019 & $200.000-300.000$ \\
\hline & 2015 & 235.000 \\
\hline & 2016 & 249.700 \\
\cline { 2 - 3 } & 2017 perintis & 263.700 \\
\hline & 2018 & $200.000-300.000$ \\
\hline & 2019 & $200.000-300.000$ \\
\hline
\end{tabular}

7. Keterhubungan Rute

Rute Sumenep - Surabaya pp. merupakan rute yang langsung terhubung dengan bandar udara pengumpul. Hal ini menjadikan penumpang mempunyai akses untuk penerbangan ke seluruh Indonesia. Pelayanan angkutan udara komersial juga memberikan kemudahan bagi penumpang yang akan melanjutkan perjalanan ke tujuan lain dengan menawarkan tiket terusan. 
Berdasarkan keterangan dari informan, mereka berasal dari Sumenep dan bekerja atau memiliki keluarga yang berada di luar Pulau Jawa, sehingga lebih memilih menggunakan angkutan udara karena mereka hanya perlu sekali membeli tiket dan tidak perlu berpindah - pindah moda transportasi. Mereka cukup menunggu di Bandara Juanda untuk transit ke penerbangan selanjutnya. Selain itu di Bandar Udara Trunojoyo saat ini juga tersedia angkutan udara perintis rute Sumenep - Bawean pp. dan Sumenep - Pagerungan pp.sehingga wilayah kepulauan di sekitar Pulau Madura semakin mudah untuk dijangkau.

\section{KESIMPULAN}

Rute angkutan udara Sumenep - Surabaya pp. adalah rute yang berhasil berkembang dari perintis menjadi komersial. Proses perkembangan ini sangat cepat jika dibandingkan dengan rute lain pada Korwil Sumenep. Faktor - faktor yang mempengaruhi perkembangan angkutan udara rute Sumenep - Surabaya pp. terdiri dari fasilitas bandar udara, dukungan pemerintah, operator penerbangan yang beroperasi, jumlah penumpang, jadwal dan frekuensi penerbangan, harga tiket dan keterhubungan dengan rute lain. Pada penelitian sebelumnya yang dilakukan oleh Yuliana (2012) faktor - faktor yang mempengaruhi perkembangan rute perintis menjadi komersial adalah potensi rute penerbangan, perusahaan angkutan udara yang beroperasi, tarif penerbangan- jaringan angkutan udara serta demand angkutan udara. Jika dibandingkan dengan penelitian sebelumnya yang dilakukan oleh Yuliana, faktor - faktor yang mempengaruhi perkembangan rute pada penelitian ini lebih beragam.

\section{DAFTAR PUSTAKA}

Ashford, N.J., Mumayiz, S., Wright, P.H. (2011). Airpot Engineering : Planning, Design, and Development of 21 st Century Airports. John Wiley \& Sons, Inc. New Jersey.

Badan Pusat Statistik, 2020. Kabupaten Sumenep dalam Angka 2019, Badan Pusat Statistik Kabupaten Sumenep. Sumenep.

Halpern, N., Graham, A. (2016). "Factors affecting airport route development activity and performance". Journal of Air Transport Management. Vol. 56, Part B, September 2016, Page $69-78$.

Halpern, N., Graham, A. (2015). "Airport route development: A survey of current practice". Tourism Management. Vol. 46, February 2015, Page. 213 - 221.

Kantor Unit Penyelenggara Bandar Udara (UPBU) Trunojoyo. (2019). Laporan Realisasi Angkutan Udara Perintis 2015 - 2019.

KM 49/05. Keputusan Menteri Perhubungan Republik Indonesia Nomor KM 49 Tahun 2005 tentang Sistem Transportasi Nasional (Sistranas).

KM 166/19. Keputusan Menteri Perhubungan Republik Indonesia Nomor KM 166 Tahun 2019 tentang Tatanan Kebandarudaraan Nasional.

KP 469/15. Keputusan Direktur Jenderal Perhubungan Udara Nomor : KP 469 Tahun 2014 tentang Rute dan Penyelenggara Subsidi Angkutan Udara Perintis serta Penyelenggara Subsidi Angkutan Bahan Bakar Minyak (BBM) Tahun Anggaran 2015.

KP 403/18. Keputusan Direktur Jenderal Perhubungan Udara Nomor KP 403 Tahun 2018 tentang Reviu Rencana Strategis (Renstra) Direktorat Jenderal Perhubungan Udara $2015-2019$.

Moleong, Lexy J. (2018). Metodologi Penelitian Kualitatif, Remaja Rosdakarya. Bandung.

Pakan, Welly. (2013). "Penerbangan Perintis dan Permasalahannyadi Maluku Utara". Warta Ardhia. Vol. 39. No. 3, September 2013, Halaman 219-229.

PM 79/17. Peraturan Menteri Perhubungan Republik Indonesia Nomor PM 79 Tahun 2017 tentang Kriteria Dan Penyelenggaraan Kegiatan Angkutan Udara Perintis dan Subsidi Angkutan Udara Kargo. 
Sartono, W., Dewanti., Rahman, T. (2017). Bandar Udara : Pengenalan dan Perancangan Geometrik Runway, Taxiway dan Apron, Gadjah Mada University Press. Yogyakarta.

Soemitro, R.A.A. \& Suprayitno, H. (2018). "Pemikiran Awal tentang Konsep Dasar Manajemen Aset Fasilitas". Jurnal Manajemen Aset Infrastruktur \& Fasilitas Vol.2. Suplemen 1, Juni 2018, Halaman 1 - 14.

Suprayitno, H. \& Soemitro, R.A.A. (2018). "Preliminary Reflection on Basic Principle of Infrastructure Aset Management”. Jurnal Manajemen Aset Infrastruktur \& Fasilitas. Vol.2, No.1, Maret 2018, Hal. : 1-10.

UU 1/09. Undang - Undang Republik Indonesia Nomor 1 Tahun 2009 tentang Penerbangan.

Yarlina, L., dan Lindasari, E. (2015). "Pengkajian Angkutan Udara Perbatasan di Kabupaten Kapuas Hulu Kalimantan Barat". Warta Ardhia. Vol. 41. No. 3, September 2015, Halaman $125-138$.

Yuliana, Dina. (2012). "Faktor - Faktor Yang Mempengaruhi Perubahan Rute Penerbangan Non Komersial (Perintis) Menjadi Rute Penerbangan Komersial". Warta Penelitian Perhubungan. Vol. 24. No. 3, Maret 2012, Halaman 273 - 282.

Yuliana, Dina. dkk. (2018). "Kajian Angkutan Udara Perintis Kargo di Propinsi Papua”. Warta Ardhia. Vol. 44. No. 2, Desember 2018, Halaman $107-122$. 
(e)ISSN 2615-1847 (p)ISSN 2615-1839

Jurnal Manajemen Aset Infrastruktur \& Fasilitas - Vol. 4, No. 2, April 2020 